\title{
$\beta$-Caseinophosphopeptide (f1-25) confers on $\beta$-casein tryptic hydrolysate an antioxidant activity during iron/ascorbate-induced oxidation of liposomes
}

\author{
Germain KANSCI $^{\mathrm{a}}$, Claude GENOT ${ }^{\mathrm{b} *}$, Anne MEYNIER ${ }^{\mathrm{b}}$, \\ Frédéric GAUCHERON ${ }^{\mathrm{c}}$, Jean-Marc CHOBERT ${ }^{\mathrm{b}}$ \\ a Laboratoire de Nutrition, Biochimie et Technologie Alimentaire, Université de Yaoundé 1, \\ BP 812 Yaoundé, Cameroun \\ b Laboratoire d'Étude des Interactions des Molécules Alimentaires, INRA, rue de la Géraudière, \\ BP 71627, 44316 Nantes Cedex 3, France \\ c UMR Science et Technologie du Lait et de l'Oeuf, INRA-Agrocampus, 65 rue de Saint Brieuc, \\ 35042 Rennes Cedex, France
}

(Received 18 August 2003; accepted 28 June 2004)

\begin{abstract}
Protein ingredients such as hydrolysates of milk proteins may improve the nutritive value of functional foods. For instance, $\beta$-casein tryptic hydrolysate could simultaneously increase iron absorption and prevent lipid oxidation in foods containing high contents of polyunsaturated fatty acids (PUFA). The aim of this study was to determine the antioxidant activity of $\beta$-casein tryptic hydrolysate and of its $\beta$-caseinophosphopeptide (f1-25) on Fe(III)/ascorbate-induced oxidation of muscle phospholipids in a liposome system. Oxygen consumption, conjugated dienes (CD), thiobarbituric acid reactive substances (TBARS) and volatile compounds were measured during oxidation at $25{ }^{\circ} \mathrm{C}$ of the liposomes in the presence of either the $\beta$-casein tryptic hydrolysate $(0.24$ $\left.2.4 \mathrm{mg} \cdot \mathrm{mL}^{-1}\right)$ or of its phosphopeptide $\left(0.1-0.31 \mathrm{mg} \cdot \mathrm{mL}^{-1}\right)$. Oxygen consumption was significantly enhanced in the presence of $\beta$-casein tryptic hydrolysate or of the phosphopeptide (f1-25) and staircase curves were observed for the highest concentrations, showing complex oxidative interactions between iron, $\beta$-casein tryptic hydrolysate or phosphopeptide and the phospholipids. In contrast, on an hourly scale, formation of CD, TBARS and total volatile compounds were inhibited. The inhibition of CD and TBARS reached $50 \%$ after $20 \mathrm{~h}$ of oxidation in the presence of $1.2 \mathrm{mg} \cdot \mathrm{mL}^{-1}$ $\beta$-casein tryptic hydrolysate or $0.16 \mathrm{mg} \cdot \mathrm{mL}^{-1}$ phosphopeptide (f1-25). Amounts of total volatile compounds produced after $24 \mathrm{~h}$ decreased by about $60 \%$ in the presence of the hydrolysate $\left(1.2 \mathrm{mg} \cdot \mathrm{mL}^{-1}\right)$ and $50 \%$ with the phosphopeptide (f1-25) $\left(0.31 \mathrm{mg} \cdot \mathrm{mL}^{-1}\right)$ due to drastic decrease or even disappearance of alkanals and 2-alkenals. Several alcohols such as pentanol and hexanol were produced in higher amounts. Thus $\beta$-casein tryptic hydrolysate can protect rich-in-PUFA phospholipid liposomes against long-term iron-induced oxidation, mainly due to iron chelation by $\beta$-caseinophosphopeptide (f1-25). This antioxidant activity could benefit specific food products.
\end{abstract}

Antioxidant activity / milk protein hydrolysate / phosphopeptide / iron chelation / liposome / lipid oxidation / muscle phospholipid / volatile compounds / oxygen consumption / TBARS

\footnotetext{
* Corresponding author: genot@nantes.inra.fr
} 
Résumé - L'hydrolysat trypsique de caséine $\beta$ protège les liposomes de l'oxydation induite par le $\mathrm{Fe}$ (III)/ascorbate grâce à la présence du $\beta$-caséinophosphopeptide (f1-25). Nous avons étudié l'effet d'un hydrolysat trypsique de caséine $\beta$ et plus particulièrement du $\beta$-caséinophosphopeptide (f1-25) sur l'oxydation, induite par le Fe(III)/ascorbate, de liposomes préparés avec des phospholipides extraits de muscle, riches en acides gras polyinsaturés. Des mesures de consommation d'oxygène, de quantités de diènes conjugués, de substances réactives à l'acide thiobarbiturique (SRTBA) et de composés volatils ont été réalisées à $25^{\circ} \mathrm{C}$ en présence de l'hydrolysat trypsique de caséine $\beta$ $\left(0,24-2,4 \mathrm{mg} \cdot \mathrm{mL}^{-1}\right)$ ou du phosphopeptide (f1-25) $\left(0,1-0,31 \mathrm{mg} \cdot \mathrm{mL}^{-1}\right)$. La consommation d'oxygène amplifiée par la présence de l'hydrolysat trypsique de caséine $\beta$ ou du phosphopeptide (f1-25) présente une courbe en escalier pour les concentrations les plus élevées, démontrant l'existence d'interactions oxydatives complexes entre le fer, l'hydrolysat ou le phosphopeptide, et les phospholipides. Pour des durées d'oxydation de l'ordre de l'heure ou plus, les quantités de produits d'oxydation des lipides formés diminuent fortement : $50 \%$ d'inhibition des quantités de diènes conjugués et de SRTBA en présence de $1,2 \mathrm{mg} \cdot \mathrm{mL}^{-1}$ d'hydrolysat de caséine $\beta$ ou de $0,16 \mathrm{mg} \cdot \mathrm{mL}^{-1}$ du peptide après $20 \mathrm{~h}$ d'oxydation ; $60 \%$ d'inhibition des quantités de composés volatils formés après $24 \mathrm{~h}$ d'oxydation en présence de $1,2 \mathrm{mg} \cdot \mathrm{mL}^{-1} \mathrm{~d}$ 'hydrolysat et $50 \%$ avec $0,31 \mathrm{mg} \cdot \mathrm{mL}^{-1}$ de peptide (f125). Les alcanals et 2-alkénals sont particulièrement touchés tandis que certains alcools comme le pentanol et l'hexanol sont produits en plus grandes quantités. Globalement, l'hydrolysat trypsique de caséine $\beta$ présente donc une activité de protection des phospholipides contre l'oxydation induite par le fer ; cette activité antioxydante est probablement en grande partie due à la chélation du métal par le $\beta$-caséinophosphopeptide (f1-25). Cette activité antioxydante ainsi que d'autres avantages nutritionnels et fonctionnels de l'hydrolysat trypsique de caséine $\beta$ pourraient inciter à l'utiliser dans des produits alimentaires spécifiques.

Activité antioxydante / Hydrolysat de protéine laitière / phosphopeptide / chélation du fer / liposomes / oxydation des lipides / phospholipides extraits de muscle / composés volatils / SRTBA / consommation d'oxygène

\section{INTRODUCTION}

The involvement of free radicals, primary and secondary products formed during lipid oxidation, and protection against their deleterious consequences in many biological processes and diseases, and during processing and storage of food products, has now been largely recognized [5, 16, 18, 28, 37, 47, 51]. Many biological materials such as muscles, milk, eggs and blood contain proteins or peptides which can exhibit an antioxidant activity [49]. The antioxidant activity of milk proteins such as lactoferrin, transferrin and caseins has been demonstrated in various systems $[2,25,46$, $49,54,56]$. Casein hydrolysates and caseinderived peptides have been shown to inhibit enzymatic and non-enzymatic lipid peroxidation [52]; caseinophosphopeptides were demonstrated to exhibit antioxidant properties in oil-in-water emulsions [14]. Iron chelation, scavenging of free radicals, and reactions of some side-chains of amino acids with hydroperoxides or secondary oxidation products, such as malonaldehyde and other aldehydes, are the main mechanisms involved in the antioxidant activity of amino acids, peptides and proteins [12, 23, $24,26,33,34,44,45]$. However, as was observed with transferrin and ferritin, the bound iron may catalyze, in certain conditions, lipid oxidation $[3,32]$. Chelation of iron modifies its redox potential, solubility and reactivity and sometimes favors initiation of lipid peroxidation [57], breakage of hydroperoxides, and development of offflavor in foods [18, 30, 31, 50].

In milk, a higher amount of iron is associated with casein micelles via phosphorylated groups than with lactoferrin. This is of nutritional interest because of the importance of iron in human health. In addition, in vitro availability of iron bound to casein phosphopeptides and net absorption of iron in animals perfused with $\beta$-caseinophosphopeptide (f1-25) are high as a result of the increase in the solubility of iron bound to 
the peptides $[1,9,48,59]$. The phosphorylated groups of casein may also play an important role in regulating the oxidation state of iron [15] and the subsequent development of lipid oxidation.

In foods, the protection of active nutriments, such as long-chain polyunsaturated fatty acid (LC-PUFA), is of particular interest $[16,21]$. The combined effects of improving the nutritive value through simultaneous enrichments in iron and LC-PUFA, increasing absorption of iron by $\beta$-caseinophosphopeptide (f1-25), and protecting the lipids against oxidation may promote the use of $\beta$-casein tryptic hydrolysates in new dietetic foods.

The aim of this study was to determine, in a liposome system made of muscle phospholipids, rich in PUFA, the antioxidant activity of $\beta$-casein tryptic hydrolysate towards iron-induced lipid oxidation, and the role played by the caseinophosphopeptide (f1$25)$ in this activity.

\section{MATERIALS AND METHODS}

\subsection{Materials}

$\beta$-Casein tryptic hydrolysates were prepared from purified bovine $\beta$-casein (variant A1) [10]. $\beta$-Caseinophosphopeptide (f1-25) was purified from $\beta$-casein tryptic hydrolysate (variant A1) according to Manson and Annan [39]. Its purity was estimated at $90 \%$ by RP-HPLC.

Piperazine-N-N' bis (2-ethanesulfonate) [PIPES] buffer solution $\left(10 \mathrm{mmol} \cdot \mathrm{L}^{-1}\right.$; $0.15 \mathrm{~mol} \cdot \mathrm{L}^{-1} \mathrm{NaCl}$ ) was prepared with ultrapure Millipore water and its $\mathrm{pH}$ adjusted to 6.0 with $\mathrm{NaOH}$. Sodium ascorbate and $\mathrm{FeCl}_{3}$ solutions were prepared daily in degassed ultrapure water. They were mixed in equimolar concentrations just before use. All other chemical reagents were of analytical grade.

\subsection{Phospholipid purification}

Lipids were extracted according to Folch et al. [17] from fresh pork muscles (Longissimus dorsi). Phospholipids (PL) were purified from the total lipid extract on a sil- icic acid column [35]. The purity of the PL was checked by a normal phase HPLC system equipped with a light-scattering detector [38]. Cholesterol and triglycerides were absent in this fraction, which contained 1.8 to $4.9 \%$ cardiolipid, 20 to $28 \%$ phosphatidyl-ethanolamine, 7.1 to $10.8 \%$ phosphatidyl-inositol, 52 to $58 \%$ phosphatidyl-choline and 1.2 to $1.8 \%$ sphingomyelin, depending on the phospholipid preparation. The fatty acids composition of the PL was determined by gas chromatography (GC) of fatty acid methyl esters (FAME) prepared according to Berry et al. [6], with the GC procedure [38]. The PL contained 34.6 to $38.7 \%$ saturated fatty acids, 22.5 to $31.2 \%$ monounsaturated fatty acids and 32.3 to $38.1 \%$ PUFA. The PUFA were composed mainly of linoleic and arachidonic acids, accounting for $26-32$ and $7-11 \%$ of total FAME, respectively. The PL were kept in chloroform at $-20{ }^{\circ} \mathrm{C}$ prior to liposome preparation.

\subsection{Liposome preparation and general procedure}

Large unilamellar vesicles (LUV) were prepared according to Hope et al. [29] to obtain liposomes with a well-defined size and stable structure, and to minimize oxidation during the preparation [22]. LUV $\left(1 \mathrm{mg} \cdot \mathrm{mL}^{-1}\right)$ were prepared in degassed PIPES buffer by extrusion through two polycarbonate membranes (Poretics Corp., London, England) of 0.4-0.45 $\mu \mathrm{m}$ porosity. Liposomes were air-saturated by bubbling filtered air at room temperature for $10 \mathrm{~min}$.

$\beta$-Casein tryptic hydrolysate (0.6 to $2.4 \mathrm{mg} \cdot \mathrm{mL}^{-1}$ ) or $\beta$-caseinophosphopeptide (f1-25) (0.16 to $\left.0.31 \mathrm{mg} \cdot \mathrm{mL}^{-1}\right)$ was dissolved in the LUV suspension to give the final concentrations. After $10 \mathrm{~min}$, phospholipid oxidation was induced by injection of an equimolar solution of $\mathrm{Fe}(\mathrm{III}) /$ ascorbate ( $45 \mu \mathrm{mol} \cdot \mathrm{L}^{-1}$ final concentration). The liposomes were incubated in closed vials at $25{ }^{\circ} \mathrm{C}$ in the dark. Lipid oxidation was assessed as described below. 


\subsection{Measurement of lipid oxidation}

\subsubsection{Oxygen consumption}

The oxygen uptake was measured with an oxygen monitor (Strathkelvin, Glasgow, UK) equipped with a Clark-type electrode and connected to a computer [20]. The electrode was calibrated with sodium dithionite ( $0 \%$ saturation) and $25^{\circ} \mathrm{C}$ air-saturated water (100\% saturation: $0.253 \mathrm{mmol} \mathrm{O} \cdot \mathrm{L}^{-1}$ ). One milliliter of the solution was pipetted into an airtight $25{ }^{\circ} \mathrm{C}$ temperature-controlled cell. Data were recorded for 25-30 min after injection of the $\mathrm{Fe}(\mathrm{III}) /$ ascorbate mixture $\left(45 \mu \mathrm{mol} \cdot \mathrm{L}^{-1}\right)$. Oxygen uptake (nmol) was calculated after 1, 5, 10, 15 and 20 min of liposome incubation with $\mathrm{Fe}(\mathrm{III}) /$ ascorbate. Measurements were performed on the liposomes in the absence or presence of $\beta$-casein tryptic hydrolysate or its phosphopeptide (f1-25). Controls were made up of PIPES buffer alone, and PIPES buffer with $\beta$-casein tryptic hydrolysate or $\beta$-caseinophosphopeptide (f1-25) to which the $\mathrm{Fe}(\mathrm{III}) /$ ascorbate mixture was added.

\subsubsection{Conjugated dienes}

The formation of conjugated dienes (CD) was evaluated after extraction of the lipids contained in $500 \mu \mathrm{L}$ incubation medium according to Folch et al. [17]. The solvent was evaporated under $\mathrm{N}_{2}$ and PL were dissolved in $2 \mathrm{~mL}$ ethanol. The lipid absorbance was recorded against ethanol from 200 to $350 \mathrm{~nm}$, using a double beam UV-Vis spectrophotometer (Varian, model Cary 13, Victoria, Australia). Formation of $\mathrm{CD}$ is characterized by the increase in the absorbance at $233 \mathrm{~nm}$ (A233). The ratio A233/A214 (A214 = isobestic point) was taken as an index of formation of primary products of oxidation [36].

\subsubsection{Thiobarbituric acid reactive substances (TBARS)}

At intervals after catalyst injection, aliquots $(0.25 \mathrm{~mL})$ of the incubation mixture were sampled from the closed vials stored at $25^{\circ} \mathrm{C}$ and TBARS were evaluated [11]. Samples were diluted into test tubes with $0.75 \mathrm{~mL}$ of water, then $2 \mathrm{~mL}$ of 2-thiobarbituric acid (TBA) reagent $[0.375 \%(\mathrm{w} / \mathrm{v})$ TBA, $15 \%(\mathrm{w} / \mathrm{v})$ trichloroacetic acid in $0.25 \mathrm{~N} \mathrm{HCl}$ ] was added. The tightly closed tubes were heated in a boiling bath for $15 \mathrm{~min}$, then cooled to room temperature under running cold tap water, and centrifuged $(2500 \times g ; 10 \mathrm{~min})$. The absorbance of the supernatant was read at $532 \mathrm{~nm}$ against a blank. The results are expressed as TBARS (nmol equivalent malonaldehyde (MDA) $\cdot \mathrm{mg}^{-1} \mathrm{PL}$ ) using the molar extinction coefficient of TBA-MDA adduct at $532 \mathrm{~nm}\left(1.56 \times 10^{5} \mathrm{~mol}^{-1} \mathrm{~cm}^{-1}\right)$ [11].

\subsubsection{Volatile compounds}

Liposomes (control) and liposomes with $\beta$-casein tryptic hydrolysate $\left(1.2 \mathrm{mg} \cdot \mathrm{mL}^{-1}\right)$ or its phosphopeptide (f1-25) $\left(0.31 \mathrm{mg} \cdot \mathrm{mL}^{-1}\right)$ were incubated at $25^{\circ} \mathrm{C}$ for $24 \mathrm{~h}$ with the $\mathrm{Fe}(\mathrm{III}) /$ ascorbate mixture $\left(45 \mu \mathrm{mol} \cdot \mathrm{L}^{-1}\right)$. $\beta$-Casein tryptic hydrolysate $\left(1.2 \mathrm{mg} \cdot \mathrm{mL}^{-1}\right)$ or its phosphopeptide $(\mathrm{fl}-25)\left(0.31 \mathrm{mg} \cdot \mathrm{mL}^{-1}\right)$ was also added to 24-h-oxidized controls. Volatile compounds were then extracted from the controls, the samples and the controls plus the hydrolysate or the phosphopeptide, then analyzed and identified using a purge and trap system (LSC 2000, Teckmar Co) coupled with a GC (HP5890; Hewlett Packard Ltd.) and a mass spectrometer (MSD 5971A, Hewlett Packard Ltd.). The experiment was performed as described in Meynier et al. [41]. The compounds were identified by comparison of the spectra with those of available libraries (NBS, NIST, TNO and INRA Mass) and using Kovats indices.

The peak areas of the identified compounds were integrated and the results expressed as follows. First, the repartition of the volatile compounds in each sample was tabulated by calculating the $\%$ area of each identified compound in the total peak area. This expression mode highlights differences in the composition of the volatile 
Table I. Effect of $\beta$-casein tryptic hydrolysate and of its caseinophosphopeptide (f1-25) on oxygen consumption during oxidation of phospholipid liposomes (PL; $\left.1 \mathrm{mg} \cdot \mathrm{mL}^{-1}\right)$ induced by $\mathrm{Fe}(\mathrm{III}) /$ ascorbate (45 $\mu \mathrm{mol} ; 1 / 1)$.

\begin{tabular}{|c|c|c|c|c|c|c|c|}
\hline \multicolumn{8}{|c|}{ Consumed oxygen (nmol) } \\
\hline \multirow[b]{2}{*}{ Time (min) } & \multicolumn{4}{|c|}{$\begin{array}{l}\beta \text {-Casein tryptic hydrolysate } \\
\left(\mathrm{mg} \cdot \mathrm{mL}^{-1}\right)\end{array}$} & \multicolumn{2}{|c|}{$\begin{array}{l}\text { } \text {-Caseinophosphopep- } \\
\text { tide }(\mathrm{f} 1-25)\left(\mathrm{mg} \cdot \mathrm{mL}^{-1}\right)\end{array}$} & \multirow{2}{*}{$\begin{array}{c}\mathrm{PL}\left(\mathrm{mg} \cdot \mathrm{mL}^{-1}\right) \\
1.0\end{array}$} \\
\hline & $2.4^{*}$ & 0.24 & 1.2 & 2.4 & 0.16 & 0.31 & \\
\hline 1 & $2 \pm 0$ & $20 \pm 1$ & $19 \pm 2$ & $21 \pm 2$ & $18 \pm 2$ & $18 \pm 2$ & $16 \pm 1$ \\
\hline 5 & $9 \pm 1$ & $27 \pm 1$ & $47 \pm 5$ & $61 \pm 5$ & $29 \pm 3$ & $56 \pm 3$ & $21 \pm 1$ \\
\hline 10 & $17 \pm 1$ & $33 \pm 1$ & $84 \pm 10$ & $84 \pm 10$ & $71 \pm 5$ & $95 \pm 5$ & $25 \pm 1$ \\
\hline 15 & $22 \pm 1$ & $39 \pm 3$ & $103 \pm 10$ & $104 \pm 10$ & $95 \pm 5$ & $124 \pm 8$ & $29 \pm 1$ \\
\hline 20 & $27 \pm 1$ & $46 \pm 3$ & $111 \pm 10$ & $120 \pm 10$ & $116 \pm 5$ & $148 \pm 6$ & $32 \pm 2$ \\
\hline
\end{tabular}

Results are the mean of triplicates obtained with the same liposome preparation. *: without PL liposomes in the medium.

extracts. Second, to estimate differences in amounts of produced volatiles better, the peak areas obtained for each compound in the presence of hydrolysate or peptide were compared with the mean values of the peak areas of the compounds measured in triplicate on controls:

Relative amount $(\mathrm{A})=\frac{[\operatorname{area}(\mathrm{A})]_{\text {sample }}}{[\text { mean area }(\mathrm{A})]_{\text {control }}} \times 100$

where A represents either a selected volatile compound or the sum of the areas of all identified volatile compounds.

\subsubsection{Data treatment}

Conjugated dienes, TBARS and oxygen uptake were measured in triplicate on at least two liposome preparations. Percentages of inhibition of conjugated dienes or TBARS were calculated from the values measured in the absence (Xo) and in the presence $(X)$ of $\beta$-casein tryptic hydrolysate or of its phosphopeptide (f1-25) at the same incubation time $[\%$ inhibition $=100$ $(1-\mathrm{X} / \mathrm{Xo})]$. The results were reported as means \pm standard deviation, and variance analysis was performed according to Snedecor and Cochran [53].

The calculated relative amounts and \% of volatile compounds extracted after $24 \mathrm{~h}$ of oxidation in the presence of the phospho- peptide (f1-25) or the $\beta$-casein tryptic hydrolysate, or after their addition to the 24-h-oxidized controls, were compared with the mean values obtained in the control considering standard deviations and variation coefficients calculated on control $(n=3)$.

\section{RESULTS}

\subsection{Oxygen consumption}

In the absence of Fe(III)/ascorbate, oxygen uptake was very low for all the samples tested $[\beta$-casein tryptic hydrolysate, phosphopeptide (f1-25) or the mixture of liposomes + either $\beta$-casein tryptic hydrolysate or phosphopeptide (f1-25)]. In agreement with Genot et al. [20], when Fe(III)/ascorbate $\left(45 \mu \mathrm{mol} \cdot \mathrm{L}^{-1}\right)$ was injected into the liposome suspension $\left(1 \mathrm{mg} \cdot \mathrm{mL}^{-1}\right)$ oxygen was consumed immediately with no lag phase. The very high rate decreased a few seconds later to become constant for the next $25 \mathrm{~min} ; \mathrm{O}_{2}$ uptake reached about $32 \mathrm{nmol}$ $\mathrm{O}_{2}$ after 20 min (Fig. 1 and Tab. I). When the $\mathrm{Fe}(\mathrm{III}) /$ ascorbate mixture was injected into solutions of the $\beta$-casein tryptic hydrolysate $\left(2.4 \mathrm{mg} \cdot \mathrm{mL}^{-1}\right)$ a similar pattern was obtained and $\mathrm{O}_{2}$ consumption was on the same order range $\left(27 \mathrm{nmol} \mathrm{O}_{2}\right.$ consumed after $20 \mathrm{~min}$; Tab. I). 


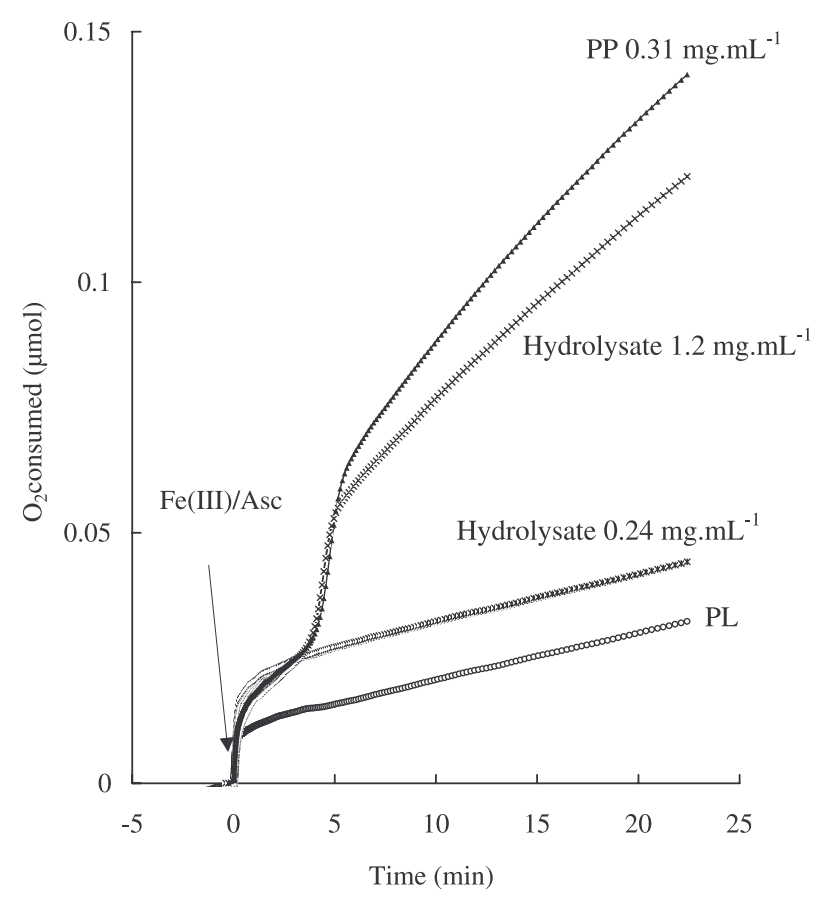

Figure 1. Oxygen uptake during Fe(III)/ascorbate-induced oxidation of phospholipid liposomes (PL, $\left.1 \mathrm{mg} \cdot \mathrm{mL}^{-1}\right)$ at $25^{\circ} \mathrm{C}$ in the presence of $\beta$-casein tryptic hydrolysate $\left(0.24\right.$ or $\left.1.2 \mathrm{mg} \cdot \mathrm{mL}^{-1}\right)$ or of $\beta$-casein phosphopeptide (f1-25) (PP, $\left.0.31 \mathrm{mg} \cdot \mathrm{mL}^{-1}\right)$. Equimolar Fe(III)/ascorbate was injected into the medium at time $0 \mathrm{~min}$, to a concentration of $45 \mu \mathrm{mol} \cdot \mathrm{L}^{-1}$. The kinetics shown are representative of $>5$ experiments.

In the presence of both the liposomes and $\beta$-casein tryptic hydrolysate $(0.24,1.2$ or $\left.2.4 \mathrm{mg} \cdot \mathrm{mL}^{-1}\right)$, oxygen consumption shot up upon $\mathrm{Fe}$ (III)/ascorbate addition (Fig. 1). The shape of the curves differed according to the hydrolysate concentration. In the presence of a low concentration of $\beta$-casein tryptic hydrolysate $\left(0.24 \mathrm{mg} \cdot \mathrm{mL}^{-1}\right)$, the shape of the curve was roughly similar to that observed in the presence of liposomes without hydrolysate. After the initial boom, that was accentuated as compared with liposomes alone, oxygen consumption became linear and paralleled the previous curve. The amount of consumed oxygen was thus higher than in the absence of the hydrolysate, at any time of storage (Tab. I). Up to 5 min after catalyst injection, similar trends were observed with higher concentrations of $\beta$-casein tryptic hydrolysate $\left(1.2 \mathrm{mg} \cdot \mathrm{mL}^{-1}\right.$ or $2.4 \mathrm{mg} \cdot \mathrm{mL}^{-1}$ ) and the amounts of $\mathrm{O}_{2}$ consumed were very close whatever the system (Tab. I). After $5 \mathrm{~min}$, the rate of oxygen consumption increased again suddenly and then decreased progressively to became constant again; remaining, however, higher than previously observed (Fig. 1). It resulted in staircase curves, showing that several reaction steps succeeded within the first 5 $10 \mathrm{~min}$ of incubation. The amount of oxygen consumed after $20 \mathrm{~min}$ of reaction was quite significant, reaching $120 \mathrm{nmol}$ for the highest hydrolysate concentration, which is about four-fold the amount consumed in control liposomes and half of the initial amount of dissolved oxygen. These experiments 
Table II. Inhibition of formation of conjugated dienes and TBARS by $\beta$-casein tryptic hydrolysate and its phosphopeptide (f1-25) in the liposome system.

\begin{tabular}{|c|c|c|c|c|c|c|c|c|}
\hline \multirow{3}{*}{$\begin{array}{l}\text { Time } \\
\text { (h) }\end{array}$} & \multirow{3}{*}{\multicolumn{2}{|c|}{ 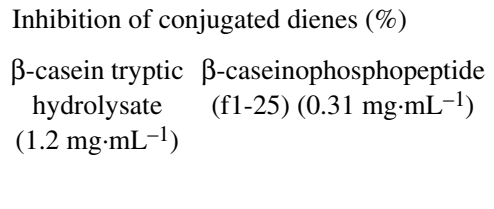 }} & \multicolumn{6}{|c|}{ Inhibition of TBARS (\%) } \\
\hline & & & \multicolumn{3}{|c|}{$\begin{array}{c}\beta \text {-casein tryptic } \\
\text { hydrolysate }\left(\mathrm{mg} \cdot \mathrm{mL}^{-1}\right)\end{array}$} & \multicolumn{3}{|c|}{$\begin{array}{l}\beta \text {-caseinophosphopeptide } \\
\quad(\mathrm{f} 1-25)\left(\mathrm{mg} \cdot \mathrm{mL}^{-1}\right)\end{array}$} \\
\hline & & & 0.6 & 1.2 & 2.4 & 0.08 & 0.16 & 0.31 \\
\hline 0.1 & $15 \pm 4$ & $24 \pm 2$ & $-31 \pm 9$ & $-20 \pm 7$ & $-21 \pm 6$ & $-62 \pm 10$ & $-48 \pm 8$ & $-21 \pm 5$ \\
\hline 2 & n.d. & n.d. & $16 \pm 4$ & $23 \pm 5$ & $22 \pm 4$ & $18 \pm 3$ & $23 \pm 3$ & $27 \pm 3$ \\
\hline 4 & n.d. & n.d. & $36 \pm 1$ & $39 \pm 2$ & $39 \pm 2$ & $36 \pm 2$ & $38 \pm 3$ & $43 \pm 2$ \\
\hline 6 & $26 \pm 3$ & $39 \pm 2$ & $39 \pm 2$ & $44 \pm 2$ & $45 \pm 2$ & $41 \pm 2$ & $44 \pm 2$ & $48 \pm 1$ \\
\hline 20 & $45 \pm 2$ & $50 \pm 1$ & $41 \pm 3$ & $51 \pm 2$ & $53 \pm 3$ & $45 \pm 2$ & $53 \pm 2$ & $58 \pm 2$ \\
\hline
\end{tabular}

TBARS and conjugated dienes values are the mean of triplicates. Inhibition percentage was calculated as follows: Inhibition $=100(1-(\mathrm{X} / \mathrm{Xo}))$, where $\mathrm{X}$ and $\mathrm{Xo}$ are the value of TBARS or conjugated dienes measured in the presence and in the absence of the effector, at the same incubation time. n.d. = not determined.

were reproducible, as shown by the low standard deviations found for oxygen consumed at different incubation times (Tab. I).

Oxygen consumption during Fe(III)/ascorbate-induced liposome oxidation was also measured in the presence of $\beta$-caseinophosphopeptide (f1-25) $\left(0.16\right.$ and $\left.0.31 \mathrm{mg} \cdot \mathrm{mL}^{-1}\right)$. As observed with the hydrolysate, after addition of $\mathrm{Fe}(\mathrm{III}) /$ ascorbate, oxygen consumption increased immediately with no lag time. The higher the peptide concentration, the higher the $\mathrm{O}_{2}$ consumption (Tab. I). Staircase curves were also obtained with the highest concentration of caseinophosphopeptide (f1-25) (0.31 mg. $\left.\mathrm{mL}^{-1}\right)$ (Fig. 1).

\subsection{Primary and secondary products of oxidation}

Conjugated dienes were measured during liposome oxidation in the presence of $\beta$-casein tryptic hydrolysate $\left(1.2 \mathrm{mg} \cdot \mathrm{mL}^{-1}\right)$ and compared with control. Less conjugated dienes were detected in the presence of the hydrolysate, whatever the incubation time. These results show that, in the presence of the hydrolysate, conjugated dienes were produced in lower amounts or more easily broken into secondary products of oxidation. The difference in amounts of conjugated dienes in controls and samples increased with time. The inhibition percentage accounted for $15 \%$ immediately after catalyst injection, $26 \%$ after $6 \mathrm{~h}$ of oxidation and $45 \%$ after $20 \mathrm{~h}$ (Tab. II). In liposomes plus $0.31 \mathrm{mg} \cdot \mathrm{mL}^{-1} \beta$-caseinophosphopeptide (f1-25), 24\% inhibition of conjugated dienes was observed immediately after catalyst injection. Fifty percent inhibition was obtained after $20 \mathrm{~h}$ of oxidation (Tab. II).

The observation was quite different when TBARS were measured. Immediately after catalyst injection, amounts of TBARS were higher in liposomes plus $\beta$-casein tryptic hydrolysate $\left(0.6,1.2\right.$, and $\left.2.4 \mathrm{mg} \cdot \mathrm{mL}^{-1}\right)$ than in the control $(+20$ to $+30 \%)$. After $2 \mathrm{~h}$ of incubation at $25^{\circ} \mathrm{C}$, they were lower in the presence of hydrolysate than in the control. 41 to $53 \%$ inhibition was observed after $20 \mathrm{~h}$ of oxidation (Tab. II). This decrease in measured TBARS as compared with control did not involve interference of the hydrolysate with the TBA test, as the measured values remained unchanged when TBARS were measured on the control (liposomes) oxidized for $20 \mathrm{~h}$, and in the same oxidized control in the presence of the hydrolysate (data not shown). The amounts of TBARS measured immediately after induction of oxidation were also higher in samples containing the phosphopeptide (f1-25) $(0.08,0.16$, 
and $0.31 \mathrm{mg} \cdot \mathrm{mL}^{-1}$ ) than in the control. After $2 \mathrm{~h}$ of oxidation, $18 \%$ and $27 \%$ inhibition of TBARS were observed in the presence of 0.08 and $0.31 \mathrm{mg} \cdot \mathrm{mL}^{-1}$ phosphopeptide (f1-25), respectively. Inhibition increased with time, reaching, after $20 \mathrm{~h}$ of reaction, $45 \%$ for the lowest concentration of phosphopeptide (f1-25) and 58\% for the highest (Tab. II). When $0.31 \mathrm{mg} \cdot \mathrm{mL}^{-1}$ phosphopeptide (f1-25) was added to the liposomes oxidized for $20 \mathrm{~h}$ at $25^{\circ} \mathrm{C}$, the amount of TBARS detected in the medium was unchanged and remained constant when the mixture was incubated again for $6 \mathrm{~h}$ at $25^{\circ} \mathrm{C}$ (data not shown).

\subsection{Volatile compounds}

Thirty-one volatile compounds were identified in the dynamic headspace extracts of the 24-hour-oxidized liposomes. As previously found [41], the major class of volatile compounds, alkanals (65\% of the total area of identified compounds; Tab. III) was mainly represented by hexanal, accounting for about half of the total area of the chromatogram. It was followed by pentanal (9.2\%). These two volatiles are typical products of oxidation of n- 6 fatty acids, which are the major oxidizable fatty acids of the pork muscle phospholipids. 2-Alkenals represented $12 \%$ of total volatiles, and among them the most representative compounds were $t$-2-octenal (4.2\%), $t$-2-heptenal (3.6\%), $t$-2-decenal $(1.3 \%)$ and $t$-2-pentenal $(0.9 \%)$. 2,4 -Alkadienals yielded nearly $4 \%$ of total volatile compounds and alcohols yielded $15 \%$ with 1 -octen-3-ol accounting for $6.1 \%$ of the total peak area, followed by pentanol $(3.6 \%)$. The proportions of the major volatiles and chemical class repartition were quite reproducible, taking into account that they were issued from different phospholipid preparations varying in fatty acid composition [42], their variation coefficient being around $25 \%$ or less. The variations of amounts of volatiles, reflecting lipid oxidability, were higher with variation coefficients usually above $50 \%$, the largest variations being observed for minor peaks. Variation of the total peak area was less than $60 \%$.
As shown in Table III, when $\beta$-casein tryptic hydrolysate $\left(1.2 \mathrm{mg} \cdot \mathrm{mL}^{-1}\right)$ was added to the liposomes before induction of oxidation, the proportions of volatile compounds produced in the volatile extract after $24 \mathrm{~h}$ at $25^{\circ} \mathrm{C}$ were largely modified. Alkanals and 2-alkenals decreased drastically (13\% of the total peak area as compared with $65 \%$ in the controls and $1 \%$ as compared with $12 \%$, respectively); 2-alkenals disappeared almost totally except for $t$-2-heptenal and $t$-2-octenal. Alcohols increased in large proportions and became predominant (nearly $80 \%$ instead of $15 \%$ ). This increase in total alcohols was mainly due to pentanol, hexanol and 1-penten-3-ol + 1-penten-3-one, which represented very large proportions in the extract (around 10,28 and 26\% of the total volatile compounds, respectively). These large proportions of alcohols in the total volatile extract reflect the fact that they were produced in high quantities in the presence of the $\beta$-casein tryptic hydrolysate: as compared with control, their amounts increased more than five-fold for hexanol and three-fold for 1-penten-3-ol + 1-penten3-one. 3-Octanone increased too, by more than 1.5 times. In contrast, amounts of most of the other volatile compounds decreased drastically. Amounts of alkanals were less than 2 to $15 \%$ of control, except for decanal that was detected in the presence of the hydrolysate but not in the control. Several 2-alkenals and most of the 2,4-alkadienals, except 2,4-decadienals, were not detected in the presence of the hydrolysate. The amount of total volatile compounds was reduced by about $80 \%$.

When $\beta$-casein tryptic hydrolysate was added to the 24-h-oxidized liposomes, the proportions of volatiles remained very similar to the control (Tab. III), only the pentanol proportion being noticeably increased (from 3.6 to $10 \%$ ). The total amounts of volatile compounds decreased, but this decrease (total amount $=60 \%$ of the control) was in the order range of variations observed on control replicates. 
Table III. Effect of $\beta$-casein tryptic hydrolysate and $\beta$-caseinophosphopeptide (f1-25) on the proportion and amounts of volatile compounds produced after $24 \mathrm{~h}$ of oxidation of phospholipid liposomes $\left(1 \mathrm{mg} \cdot \mathrm{mL}^{-1}\right)$

\begin{tabular}{|c|c|c|c|c|c|c|c|c|c|c|c|}
\hline \multirow{4}{*}{ Compound } & \multirow{2}{*}{\multicolumn{3}{|c|}{$\begin{array}{l}\text { Oxidized liposomes } \\
\text { (control) }\end{array}$}} & \multicolumn{4}{|c|}{$\beta$-casein tryptic hydrolysate $\left(1.2 \mathrm{mg} \cdot \mathrm{mL}^{-1}\right)$} & \multicolumn{4}{|c|}{$\beta$-caseinophosphopeptide (fl-25) $\left(0.31 \mathrm{mg} \cdot \mathrm{mL}^{-1}\right)$} \\
\hline & & & & \multicolumn{2}{|c|}{$\begin{array}{l}\text { Liposomes }+ \text { hydrolysate } \\
\text { added before oxidation }\end{array}$} & \multicolumn{2}{|c|}{$\begin{array}{c}\begin{array}{l}\text { Oxidized liposomes }+ \\
\text { hydrolysate at } t=24 \mathrm{~h}\end{array}\end{array}$} & \multicolumn{2}{|c|}{$\begin{array}{l}\text { Liposomes + hydrolysate } \\
\text { added before oxidation }\end{array}$} & \multicolumn{2}{|c|}{$\begin{array}{l}\text { Oxidized liposomes }+ \\
\text { hydrolysate at } \mathrm{t}=24 \mathrm{~h}\end{array}$} \\
\hline & \multicolumn{3}{|c|}{ proportions (\% total area) } & proportion & relat. amount & proportion & relat. amount & Proportion & Relat. amount & Proportion $\mathrm{F}$ & Relat. amount \\
\hline & mean & std & $\mathrm{VC}$ & (\% total area) & (\% control) & (\% total area) & (\% control) & (\% total area) & (\% control) & (\% total area) & (\% control) \\
\hline pentanal & 9.2 & 2.4 & 26 & 2.0 & 3 & 7.3 & 45 & 3.2 & 8 & 8.8 & 47 \\
\hline hexanal & 48.0 & 4.8 & 10 & 5.1 & 2 & 46.4 & 61 & 26.6 & 14 & 42.4 & 48 \\
\hline heptanal & 2.6 & 1.5 & 59 & 0.7 & 4 & 2.0 & 38 & 1.7 & 13 & 1.4 & 24 \\
\hline octanal & 1.8 & 0.3 & 18 & 0.8 & 8 & 1.4 & 44 & 1.3 & 16 & 1.8 & 49 \\
\hline nonanal & 3.3 & 0.6 & 17 & 2.7 & 15 & 3.6 & 68 & 3.3 & 25 & 4.1 & 68 \\
\hline decanal & 0.0 & 0.0 & 0 & 1.4 & - & 0.9 & - & 1.3 & - & 1.3 & - \\
\hline Alkanals & 65 & 3.3 & 5 & 13 & 3 & 62 & 58 & 37 & 14 & 60 & 49 \\
\hline$t-2$-pentenal & 0.9 & 0.6 & 74 & 0.0 & 0 & 2.0 & 191 & 0.0 & 0 & 0.8 & 68 \\
\hline $\mathrm{t}$-2-hexenal & 0.5 & 0.1 & 27 & 0.0 & 0 & 0.4 & 47 & 0.0 & 0 & 0.4 & 43 \\
\hline t-2-heptenal & 3.6 & 0.8 & 22 & 0.4 & 2 & 2.3 & 40 & 1.7 & 12 & 3.7 & 56 \\
\hline $\mathrm{t}-2$-octenal & 4.2 & 0.7 & 17 & 0.6 & 2 & 2.8 & 40 & 1.7 & 9 & 4.7 & 57 \\
\hline $\mathrm{t}$-2-nonenal & 0.7 & 0.3 & 41 & 0.0 & 0 & 0.4 & 28 & 0.7 & 21 & 0.6 & 40 \\
\hline $\mathrm{t}$-2-decenal & 1.3 & 0.5 & 38 & 0.0 & 0 & 0.8 & 31 & 0.6 & 9 & 1.2 & 43 \\
\hline $\mathrm{t}$-2-undecenal & 0.6 & 0.5 & 88 & 0.0 & 0 & 0.0 & 0 & 0.0 & 0 & 0.0 & 0 \\
\hline 2-Alkenals & 12 & 0.7 & 6 & 1 & 1 & 9 & 45 & 5 & 10 & 11 & 51 \\
\hline t,t-2,4-heptadienal & 0.3 & 0.2 & 60 & 0.0 & 0 & 0.3 & 64 & 0.4 & 34 & 0.4 & 75 \\
\hline t,c-2,4-nonadienal & 0.5 & 0.4 & 88 & 0.0 & 0 & 0.8 & 134 & 0.0 & 0 & 1.1 & 166 \\
\hline $\mathrm{t}, \mathrm{t}-2,4$-nonadienal & 1.4 & 0.6 & 42 & 0.0 & 0 & 1.4 & 52 & 0.2 & 4 & 2.0 & 65 \\
\hline t,c-2,4-decadienal & 0.6 & 0.6 & 93 & 1.1 & 42 & 1.0 & 133 & 1.2 & 60 & 1.4 & 164 \\
\hline $\mathrm{t}, \mathrm{t}-2,4$-decadienal & 1.2 & 0.7 & 58 & 1.4 & 20 & 2.3 & 113 & 1.4 & 27 & 3.3 & 143 \\
\hline 2,4-Alkadienals & 4 & 1.1 & 27 & 2 & 11 & 6 & 89 & 3 & 20 & 8 & 111 \\
\hline pentanol & 3.6 & 1.7 & 47 & 10.5 & 43 & 10.3 & 146 & 30.5 & 171 & 3.5 & 43 \\
\hline hexanol & 1.0 & 0.6 & 62 & 27.7 & 570 & 0.6 & 46 & 7.2 & 200 & 0.3 & 16 \\
\hline heptanol & 0.6 & 0.3 & 47 & 1.9 & 50 & 0.6 & 55 & 1.0 & 36 & 0.4 & 35 \\
\hline 1-hexanol-2-ethyl & 1.4 & 1.7 & 121 & 3.0 & 27 & 0.4 & 12 & 1.2 & 15 & 0.9 & 26 \\
\hline octanol + 3,5-octadien-2-one & 1.3 & 0.7 & 56 & 3.2 & 35 & 1.3 & 51 & 2.4 & 36 & 1.7 & 57 \\
\hline 1-octen-3-ol & 6.1 & 1.5 & 26 & 6 & 16 & 4 & 43 & 6 & 22 & 7 & 60 \\
\hline 1-penten-3-ol + 1-penten-3-one & 1.3 & 0.4 & 28 & 25.8 & 366 & 3.5 & 171 & 1.4 & 28 & 2.4 & 101 \\
\hline Alcohols & 15 & 3.9 & 26 & 78 & 140 & 21 & 131 & 49 & 121 & 16 & 88 \\
\hline 2-heptanone & 0.3 & 0.3 & 99 & 0.0 & 0 & 0.0 & 0 & 0.0 & 0 & 0.2 & 40 \\
\hline 3-octanone & 0.2 & 0.1 & 87 & 1.7 & 166 & 0.2 & 67 & 0.9 & 123 & 0.3 & 77 \\
\hline 3-octen-2-one & 0.7 & 0.2 & 22 & 1.0 & 21 & 0.9 & 68 & 0.8 & 23 & 0.9 & 63 \\
\hline 3,5-octadien-2-one & 0.6 & 0.5 & 87 & 1.4 & 55 & 0.0 & 0 & 0.9 & 46 & 0.0 & 0 \\
\hline 2-pentyl-furan $+2,4$-heptadienal & 2.1 & 0.2 & 8 & 1.9 & 16 & 2.0 & 58 & 2.7 & 31 & 2.9 & 75 \\
\hline Total & 100.0 & $57^{*}$ & $57^{*}$ & 100.0 & 17 & 100.0 & 60 & 100.0 & 24 & 100.0 & 52 \\
\hline
\end{tabular}

Control: $n=3$; samples: $n=1$; VC: variation coefficient. *: standard deviation (std) and VC of total amounts of volatiles calculated for a mean total amount set at 100 [total volatile amount $=$ total peak area $\times 100 /$ mean (total peak area)] 
The proportions and amounts of volatile compounds measured after $24 \mathrm{~h}$ of oxidation of PL liposomes in the presence of liposomes plus $0.31 \mathrm{mg} \cdot \mathrm{mL}^{-1} \beta$-caseinophosphopeptide (f1-25) were also modified (Tab. III). The amounts of total volatile compounds decreased by about $75 \%$ as compared with the control. In fact, amounts of most of the individual volatile compounds were reduced; only amounts of hexanol and pentanol increased. Consequently, the proportions of some volatile compounds, such as alkanals (from $65 \%$ to $37 \%$ of total volatiles in the control) and 2-alkenals (from 12 to $5 \%$ ), were largely decreased, and those of alcohols increased (from 15 to about 50\%) (Tab. III).

When $\beta$-caseinophosphopeptide (f1-25) was added to the previously oxidized liposomes, the proportions of volatile compounds were only slightly modified (Tab. III). However, the amounts of most volatile compounds decreased; in particular, $t$-2undecenal totally disappeared. As a consequence, the total amount of volatiles extracted from the oxidized control after addition of the phosphopeptide tented to decrease.

\section{DISCUSSION}

The aim of this study was to determine the antioxidant activity of $\beta$-casein tryptic hydrolysate and of its $\beta$-caseinophosphopeptide (f1-25) on $\mathrm{Fe}(\mathrm{III}) /$ ascorbate-induced oxidation of muscle phospholipids in a liposome system. The results show that $\beta$-casein tryptic hydrolysate and $\beta$-caseinophosphopeptide (f1-25) have a complex impact on iron-induced liposome oxidation. At the earliest incubation times after injection of the iron-ascorbate mixture, oxygen consumption and amounts of TBARS were significantly increased in the presence of the hydrolysate or the peptide. In contrast, on the hourly or daily scales, the amounts of conjugated dienes, TBARS and volatile compounds decreased in significant proportions. The very similar behavior of the hydrolysate and the phosphopeptide added at equivalent molar concentrations indicates that most of the activity of the hydrolysate is due to the phosphopeptide.

The lowest amounts of conjugated dienes, TBARS and volatile compounds measured in the presence of $\beta$-casein hydrolysate or $\beta$-caseinophosphopeptide (f1-25) indicate that these compounds protected the PL liposomes against long-term iron-induced oxidation and exhibited antioxidant activity. Conjugated dienes are primary products of oxidation, which result from the migration of one double bond of the PUFA, after hydrogen abstraction in the initial stage of lipid oxidation. The hydroperoxides issued from the oxidation of the PUFA of the muscle phospholipids present this conjugated structure and are thus quantified with the UV method. These compounds are easily broken, in the presence of iron, into secondary products of oxidation. Lower amounts of conjugated dienes in the liposomes oxidized in the presence of the hydrolysate or the phosphopeptide, as compared with the controls, corresponded either to a protection of the unsaturated fatty acids against initiation of lipid oxidation, or to their enhanced breakdown. TBARS are secondary products of lipid oxidation that react with 2-thiobarbituric acid to give a pink chromogen. TBARS include molecules such as malonaldehyde, 2,4-alkadienals and, to a lesser extent, 2-alkenals. As no antioxidant, such as butyl hydroxytoluene, was added to the reaction mixture, the measured TBARS values resulted from both TBARS actually present in the oxidizing liposomes and TBARS formed, at boiling temperature, during the TBA test. Consequently, in the conditions used, measurement of TBARS gave an overall view of development of lipid oxidation in the systems tested. Interference of the TBA test with several compounds was previously observed, such as, for example, with carnosine added to oxidizing liposomes [34]. Such an interference did not take place in the presence of the $\beta$-casein hydrolysate or the peptide (f1-25), as TBA values were unchanged when the test was performed on oxidized liposomes to which the protein derivatives were added. 
Thus, lower quantities of TBARS detected in the presence of the $\beta$-casein hydrolysate or the peptide (f1-25) actually signified lower amounts of primary and/or secondary products of lipid oxidation in the system. Higher inhibition percentages were measured for TBARS than for conjugated dienes when the oxidation time was over $2 \mathrm{~h}$, showing that a favored breakdown of conjugated dienes in the presence of the peptide compounds is unlikely. The inhibition was even more marked when amounts of volatile compounds typical of secondary products of lipid oxidation, such as alkanals, 2-alkenal and 2,4alkadienals, were considered. As the decreases in volatile amounts were low when the peptides were added to the already oxidized liposomes, interactions or reactions of the volatiles with the peptides [43], reducing their release from the liposomes during dynamic headspace analysis, can hardly explain the observed inhibition. $\beta$-Casein tryptic hydrolysate and $\beta$-caseinophosphopeptide (f1-25) inhibited, on the hourly scale, the formation of both primary (conjugated dienes) and secondary (TBARS and volatile compounds, particularly alkanals and 2-alkenals) products of lipid oxidation when the degradation of PL liposomes was initiated by the iron-ascorbate redox mixture. This could result from the binding of iron to the phosphopeptide, limiting both initiation of the reaction and breakage of the hydroperoxides. Free radical scavenging by the peptides, or reactions of peroxidizing lipids with amino groups of the protein hydrolysate, causing losses in reacting amino acids, cannot be excluded [23, 52]. Loss of methionine during storage of casein and of lysyl, tryptophanyl and histidyl residues of whey proteins were observed previously in the presence of oxidizing methyl linoleate $[7,45,55]$.

In contrast to other measurements, oxygen consumption, measured during the first 20 min of reaction, and TBARS measured immediately after iron-ascorbate addition were remarkably enhanced when the $\beta$-casein tryptic hydrolysate or the phosphopeptide (f1-25) were added. Apart from lipid oxi- dation, which was inhibited as previously demonstrated, oxygen consumption in the presence of iron can result from (i) oxidation of some amino acid residues, (ii) oxidation of $\mathrm{Fe}$ (II) to $\mathrm{Fe}$ (III), and (iii) formation of ferric complexes or other chelate complexes [15, 40, 57]. For instance, formation of ATP-, ADP- or EDTA-Fe ${ }^{3+}$ complexes was associated with oxygen uptake [40]. In the present work, oxygen consumption was remarkably high when the three components, namely phospholipid liposomes, iron and $\beta$-casein tryptic hydrolysate or $\beta$-caseinophosphopeptide (f1-25) were simultaneously present. Typical staircase curves were observed. When only two of these components were added (iron + phospholipids or iron + hydrolysate) oxygen uptake also occurred, but to a far smaller extent. Hence, the dramatic oxygen consumption in the presence of phospholipids, iron and peptides is the consequence of oxidative interactions between the three components. As shown by the staircase curves, the interaction involved different successive steps, taking place in the few first minutes of reaction. It was not directly related to lipid oxidation, but it could participate in the later inhibition of lipid oxidation.

The results show that $\beta$-caseinophosphopeptide (f1-25) plays a major part in the antioxidant activity of the hydrolysate. Changes in $\mathrm{O}_{2}$ consumption, amounts of conjugated dienes, TBARS and volatile compounds in the liposome system with $\beta$-casein tryptic hydrolysate or its phosphopeptide (f1-25) were very similar. After $20 \mathrm{~h}$ of oxidation, the concentration of $\beta$-casein tryptic hydrolysate needed to obtain $50 \%$ inhibition of TBARS and conjugated dienes was about $1.2 \mathrm{mg} \cdot \mathrm{mL}^{-1}$, that is, about $50 \mu \mathrm{mol} \cdot \mathrm{L}^{-1}$ equivalent $\beta$-casein. It was $0.1-0.16 \mathrm{mg} \cdot \mathrm{mL}^{-1}$ for $\beta$-caseinophosphopeptide (f1-25), that is about $20 \mu \mathrm{mol} \cdot \mathrm{L}^{-1}$. After $24 \mathrm{~h}$ of oxidation, about $75 \%$ inhibition of the amount of volatile compounds was observed in the presence of $1.2 \mathrm{mg} \cdot \mathrm{mL}^{-1} \beta$-casein tryptic hydrolysate. The same inhibition was observed in the presence of $0.31 \mathrm{mg} \cdot \mathrm{mL}^{-1} \beta$-caseinophosphopeptide (f1-25) only. The activity 
of the phosphopeptide was not due to modifications of the structure or of the physical state of the liposome, since the peptide did not modify the fluorescence anisotropy of 1,6-diphenyl-1,3,5-hexatriene included in the liposome [33]. The presence of a "negative cluster" of phosphoseryl residues at the positions $15,17,18$ and 19 enables iron chelation [4]. This cluster plays an important role since the affinity of $\beta$-caseinophosphopeptide (f1-25) (4 phosphoseryl residues) for chelating iron [4 to 6 atoms/ mol $\beta$-caseinophosphopeptide (f1-25)] is greater than that of the other $\beta$-casein phosphopeptide (f33-48) containing only one phosphoseryl residue $[4,8,19,27,58]$. Chelation of iron decreases its availability and its catalytic efficiency [13], but induces oxygen consumption during fixation and oxidation of the metal ion. The initiation of lipid oxidation or the decomposition of hydroperoxides by iron are reduced, which is in agreement with the observed decreases in amounts of conjugated dienes and secondary products of lipid oxidation. The phosphoryl group of the phospholipids is also involved in the overall oxidative interactions, as shown from the oxygen uptake results. The staircase curves obtained with this method indicate that complex interactions are involved, which will need special attention in further studies.

\section{CONCLUSION}

$\beta$-Casein tryptic hydrolysate exhibited antioxidant activity against iron/ascorbateinduced oxidation of rich-in-PUFA phospholipid liposomes, as shown by decreased amounts of conjugated dienes, TBARS and total volatile compounds. These effects were mainly due to the $\beta$-caseinophosphopeptide (f1-25). The significant oxygen consumption when the peptide or the hydrolysate, the phospholipids and iron/ ascorbate were together present, evidenced complex oxidative interactions between constituents. The modifications of the profiles of volatile compounds in the presence of the hydrolysate or the phosphopeptide (f1-25) could benefit to the flavor of special foods where they would increase iron availability and protect against PUFA oxidation.

\section{REFERENCES}

[1] Aït-Oukhatar N., Bouhallab S., Bureau F., Drodowsky M., Maubois J.L., Arhan P., Bouglé D., Bioavailability of caseinophosphopeptide bound iron in young rat, J. Nutr. Biochem. 8 (1997) 190-194.

[2] Allen J.C., Wrieden W.L., Influence of milk proteins on lipid oxidation in aqueous emulsion. I. Casein, whey protein and $\alpha$-lactalbumin, J. Dairy Res. 49 (1982) 239-248.

[3] Ahn D.U., Kim S.M., Prooxidant effects of ferrous iron, hemoglobin, and ferritin in oil emulsion and cooked-meat homogenates are different from those in raw-meat homogenates, Poultry Sci. 77 (1998) 348-355.

[4] Bernos E., Girardet J.-M., Humbert G., Linden G., Role of the O-phosphoserine clusters in the interaction of the bovine milk $\alpha_{\mathrm{s} 1^{-}}, \beta$-, $\kappa$-caseins and the PP3 component with immobilized iron(III) ions, Biochim. Biophys. Acta 1337 (1997) 149-159.

[5] Berr C., Coudray C., Bonithon-Kopp C., Roussel A.-M., Mainard F., Alperovitch A., Demographic and cardiovascular risk factor in relation to antioxidant status. The EVA study, Int. J. Vit. Nutr. Res. 68 (1998) 26-35.

[6] Berry J.F., Cevallos, W.H., Wade R.R., Lipid class and fatty acid composition of intact peripheral nerve and during Wallerian degeneration, J. Amer. Oil Chem. Soc. 42 (1965) 492-500.

[7] Bishov S.J., Henick A.S., Antioxidant effect of protein hydrolysates in freeze-dried model systems-synergistic action with a series of phenolic antioxidants, J. Food Sci. 40 (1975) 345-348.

[8] Bouhallab S., Léonil J., Maubois J.L., Complexation du fer par le phosphopeptide (1-25) de la caséine $\beta$ : action de l'alcalase et de la phosphatase acide, Lait 71 (1991) 435-443.

[9] Bouhallab S., Cinga V., Ait-Outkhatar N., Bureau F., Neuville D., Arkhan P., Maubois J.L., Bouglé D., Influence of various phosphopeptides of caseins on iron absorption, J Agric. Food Chem. 50 (2002) 7127-7130.

[10] Briand L., Chobert J.-M., Haertlé T., Tryptic hydrolysis of esterified $\beta$-casein and $\beta$-lactoglobulin, Milchwissenschaft 49 (1994) $367-$ 371.

[11] Buege J.A., Aust S.D., Microsomal lipid peroxidation, in: Fleischer S.F., Packer L., 
(Eds.), Biomembranes (Part C. Biological oxidation), Methods in Enzymology, Academic Press, London, UK, 1978, pp. 302-310.

[12] Chen Z.Y., Nawar W.W., The role of amino acids in the autoxidation of milk fat, J. Am. Oil Chem. Soc. 68 (1991) 47-50.

[13] Decker E.A., Hultin H.O., Lipid oxidation in foods via redox iron, in: St Angelo A.J. (Ed.), Lipid oxidation in foods, ACS Symposium series 500, Washington, USA, 1992, pp. 35-54

[14] Diaz M., Dunn C.M., McClements D.J., Decker E.A., Use of caseinophosphopeptides as natural antioxidants in oil-in-water emulsions, J. Agric. Food Chem. 51 (2003) 23652370.

[15] Emery T., Iron oxidation by casein, Biochem. Biophys. Res. Commun. 182 (1992) $1047-$ 1052.

[16] Eritsland J., Safety considerations of polyunsaturated fatty acids, Amer. J. Clinical Nutr. 71 (2000) 197-201.

[17] Folch J., Lees M., Sloane-Stanley G.H., A simple method for the isolation and purification of total lipids from animal tissues, J. Biol. Chem. 226 (1957) 497-509.

[18] Frankel E.N., Lipid oxidation, The Oily Press, Dundee, GB, 1998.

[19] Gaucheron F., Mollé D., Léonil J., Maubois J.L., Selective determination of phosphopeptide $\beta-\mathrm{CN}(1-25)$ in a $\beta$-casein digest by adding iron: characterization by liquid chromatography with on-line electrospray-ionisation-mass spectrometric detection, J. Chromatogr. B. 664 (1995) 193-200.

[20] Genot C., Kansci G., Laroche M., Measurement of phospholipid oxidation in model membranes by determination of oxygen consumption with a semi-automatic polarographic method, Sci. Aliments 14 (1994) 679-688.

[21] Genot C., Eymard S., Viau M., Comment protéger les acides gras polyinsaturés à longues chaînes $\omega 3$ (AGPI-LC $\omega 3$ ) vis-à-vis de l'oxydation ? O.C.L. 11 (2004) 133-141.

[22] Genot C., Métro B., Viau M., Bouchet B., Characterisation and stability during storage of liposomes made of muscle phospholipids, Lebensm.-Wiss. U.-Technol. 32 (1999) 167174.

[23] Genot C., Meynier A., Riaublanc A., Chobert J.M., Protein alterations due to lipid oxidation in multiphase systems, in: Kamal-Eldin A. (Ed.), Lipid oxidation pathways, AOCS Press, Champaign, USA, 2003, pp. 266-292.

[24] Gordon M.H., The mechanism of antioxidant action in vitro, in: Hudson B.J.F. (Ed.), Food antioxidants, Elsevier, London, UK, 1990, pp. $1-18$.
[25] Gutteridge J.M.C., Paterson S.K., Segal A.W., Halliwell B., Inhibition of lipid peroxidation by the iron-binding protein lactoferrin, Biochem. J. 199 (1981) 259-261.

[26] Halliwell B., Gutteridge J.M.C., Role of free radicals and catalytic metal ions in human disease: An overview, in: Packer L., Glazer A.N. (Eds.), Oxygen radicals in biological systems (Part B: Oxygen radicals and antioxidants), Methods in Enzymology, 186, Academic Press, San Diego, USA, 1990, pp.1-85.

[27] Hegenauer J., Saltman P., Nace G., Iron(III)phosphoprotein chelates: stoichiometric equilibrium constant for interaction of iron(III) and phosphorylserine residues of phosvitin and casein, Biochemisty, 18 (1979) 3865-3879.

[28] Hercberg S., Galan P., Preziosi P., Roussel A.-M., Arnaud J., Richard M.-J., Malvy D., Paul-Dauphin A., Briançon S., Favier A., Background and rationale behind the SU.VI.MAX study, a prevention trial using nutritional doses of a combination of antioxidant vitamins and minerals to reduce cardiovascular diseases and cancers, Int. J. Vit. Nutr. Res. 68 (1998) 3-20.

[29] Hope M.J., Bally M.B., Wegg G., Cullis P.R., Production of large unilamellar vesicles by a rapid extrusion procedure. Characterisation of size distribution, trapped volume and ability to maintain a membrane potential, Biochim. Biophys. Acta 812 (1985) 55-65.

[30] Jacobsen C., Hartvigsen K., Thomsen M.K., Hansen L.F., Lund P., Skibsted L.H., Holmer G., Adler-Nissen J., Meyer A.S., Lipid oxidation in fish oil enriched mayonnaise: calcium disodium ethylenediaminetetracetate, but not gallic acid, strongly inhibited oxidative deterioration, J. Agric. Food Chem. 49 (2001) 1009-1019.

[31] Jacobsen C., Sensory impact of lipid oxidation in complex food systems, Fett/Lipid 101 (1999) 484-492.

[32] Kanner J., German J.B., Kinsella J.E., Initiation of lipid peroxidation in biological systems, CRC Crit. Rev. Food Sci. Nutr. 25 (1987) 317-365.

[33] Kansci G., Effets antioxidants de peptides et d'hydrolysats de protéines sur l'oxydation des phospholipides. Thèse de Doctorat, ENSAR, Rennes, France, 1996.

[34] Kansci G., Genot C., Meynier A., Gandemer G., The antioxidant activity of carnosine and its consequences on the volatile profiles of liposomes during iron-ascorbate induced phospholipid oxidation, Food Chem. 62 (1997) 165-175.

[35] Kates M., Separation of lipid mixtures, in: Work T.S., Work E. (Eds.), Techniques of 
lipidology. Isolation, analysis and identification of lipids, 3rd edn., North Holland Publisher Company, Amsterdam, The Netherlands, 1982, pp. 393-469.

[36] Klein R.A., The detection of oxidation in liposomes preparation, Biochim. Biophys. Acta 210 (1970) 486-489.

[37] Kubow S., Routes of formation and toxic consequences of lipid oxidation products in foods, Free Rad. Biol. Medec. 12 (1992) 6381.

[38] Leseigneur-Meynier A., Gandemer G., Lipid composition of pork muscle in relation to the metabolic type of the fibres, Meat Sci. 29 (1991) 229-241.

[39] Manson W., Annan W.D., The structure of a phosphopeptide derived from $\beta$-casein, Arch. Biochem. Biophys. 145 (1971) 16-26.

[40] Manson W., Cannon J., The reaction of $\alpha_{\mathrm{s} 1^{-}}$ and $\beta$-casein with ferrous ions in the presence of oxygen, J. Dairy Res. 45 (1978) 59-67.

[41] Meynier A., Genot C., Gandemer G., Volatile compounds of oxidized pork phospholipids, J. Am. Oil Chem. Soc. 75 (1998) 1-7.

[42] Meynier A., Genot C., Gandemer G., Oxidation of muscle phospholipids in relation to their fatty acid composition, with emphasis on volatile compounds, J. Sci. Food Agric. 79 (1999) 797-804.

[43] Meynier A., Rampon V., Dalgalarrondo M., Genot C., Hexanal and t-2-hexenal form covalent bonds with whey proteins and sodium caseinate in aqueous solution, Int. Dairy J. 14 (2004) 681-690.

[44] Nielsen H.K., Covalent binding of peroxidized phospholipid to protein: III. Reaction of individual phospholipids with different proteins, Lipids 16 (1981) 215-222.

[45] Nielsen H.K., Löliger J., Hurrell R.F., Reactions of proteins with oxidizing lipids. Analytical measurements of lipid oxidation and amino acid losses in a whey protein-methyl linolenate model system, British J. Nutr. 53 (1985) 61-73.

[46] O'Connor T.P., O’Brien N.M., Lipid oxidation, in: Fox P.F. (Ed.), Advanced Dairy Chemistry-2: Lipids, Chapman \& Hall, London, UK, 1994, pp. 309-347.

[47] Penumetcha M., Khan N., Parthasarathy S., Dietary oxidized fatty acids: an atherogenic risk?, J. Lipid Res. 41 (2000) 1473-1480.
[48] Peres J.M., Bouhallab S., Bureau F., Maubois J.L., Arhan P., Bouglé D., Absorption digestive du fer lié au caséinophosphopeptide 1-25 de la caséine $\beta$, Lait 77 (1997) 433-440.

[49] Pratt D.E., Hudson B.J.F., Natural antioxidants not exploited commercially, in: Hudson B.J.F. (Ed.), Food antioxidants, Elsevier Science, New York, USA, 1990, pp. 171-191.

[50] Rice W.H., McMahon D.J., Chemical, physical, and sensory characteristics of mozzarella cheese fortified using protein-chelated iron of ferric chloride, J. Dairy Sci. 81 (1998) 318-326.

[51] Riemersma R.A., Analysis and possible significance of oxidised lipids in food, Eur. J. Lipid Sci. Technol. 104 (2002) 419-420.

[52] Rival S.G., Boeriu C.G., Wichers H.J., Caseins and casein hydrolysates. 2. Antioxidative properties and relevance to lipoxygenase inhibition, J. Agric. Food Chem. 49 (2001) 295-302.

[53] Snedecor G.W., Cochran W.G., Statistical methods, 7th edn., The Iowa State University Press, Iowa, USA, 1980.

[54] Satué-Gracia M.T., Frankel E.N., Rangavajhyala N., German J.B., Lactoferrin in infant formulas: effect on oxidation, J. Agric. Food Chem. 48 (2000) 4984-4990.

[55] Tannenbaum S.R., Barth H., Le Roux J.P., Loss of methionine in casein during storage with autoxidizing methyl linoleate, J. Agric. Food Chem. 17 (1969) 1353-1354.

[56] Taylor M.J., Richardson T., Antioxidant activity of cysteine and protein sulfhydryls in a linoleate emulsion oxidized by hemoglobin, J. Food Sci. 45 (1980) 1223-1227.

[57] Tien M., Morehouse L.A., Bucher J.R., Aust S.D., The multiple effects of ethylene diamine tetra acetate in several model lipid peroxidation systems, Arch. Biochem. Biophys. 218 (1982) 450-458.

[58] Vegarud G.E., Langsrud T., Svenning C., Mineral-binding milk proteins and peptides; occurence, biochemical and technological characteristics, British J. Nutr. 84 (Suppl 1) (2000) S91-S98.

[59] Yeung A.C., Glahn R.P., Miller D.D., Effect of iron source on iron availability from casein and casein phosphopeptides, J. Food Sci. 67 (2002) 1271-1275. 